\title{
The Tribe of Ishmael:
}

\section{Al Ftuop in Focial Đegradation.}

\section{Jisy Oscar C. SiscCullocb.}

\author{
$\square \because \square \cdot$
}

The studies of Ray Lankaster into "Degeneration" are not only interesting to the student of physical science, but suggestive to the student of social science.

He takes a minute organism which is found attached to the body of the hermit crab. It has a kidney-beanshaped body, with a bunch of root-like processes through which it sucks the living tissues of the crab. It is known as the Sacculina. It is a crustacean which has left the free, independent life common to its family, and is living as a parisite, or pauper. The young have the Nauplius form belonging to all crustacea : it is a free swimmer. But very soon after birth a change comes over it. It attaches itself to the crab, loses the characteristics of the higher class, and becomes degraded in form and function. An irresistible heriditary tendency siezes upon it, and it succumbs. A hereditary tendency I say, because some remote ancestor left its independent, self-helpful life, and began a parasitic, or pauper, life. Not using its organs for self-help, they one by one have disappeared,-legs and other members,- - until there is left a shapeless mass, with only the stomach and organs of reproduction left. This tendency to parasitism was transmitted to its descendants, until there is set up an irresistible hereditary tendency; and the Sacculina stands in nature as a type of degradation through parasitism, or pauperism. 
I propose to trace the history of similar degradation in man. It is no pleasant study, but it may be relied upon as fact. It is no isolated case. It is not peculiar to Indiana. In all probability, similar study would show similar results in any of our States. It resembles the study of Dr. Dugdale into the Jukes, and was suggested by that. It extends, however, over a larger field, comprising over two hundred and fifty known families, thirty of which have been taken out as typical cases, and diagramed here. The name, "the tribe of Ishmael," is given because that is the name of the central, the oldest, and the most widely ramified family.

In the late fall of 1877 , I visited a case of extreme destitution. There were gathered in one room, without fire, an old blind woman, a man, his wife and one child, his sister and two children. A half-bed was all the furnishing. No chair, table, or cooking utensils. I provided for their immediate wants, and then looked into the records of the township trustee. I found that I had touched a family known as the Ishmaels, which had a pauper history of several generations, and so intermarried with others as to form a pauper ganglion of several hundreas. At the Conference at Cleveland, I reported this case. The investigations have since been extended. Year by year the record has grown. Historical data of two hundred and fifty families have been gathered, and on the accompanying diagram thirty families are traced. This diagram is prepared by Mrs. Kate F. Parker, registrar of the Charity Organization Society, and Mr. Frank Wright, detailed by the county commissioners to assist in the prosecution of this investigation. The number of families here studied is thirty. Of these, only two are known before 1840. They are found here at that time.

The central family - that which gives its name to the tribe of Ishmael-first appears in Indianapolis about 1840. The original family stem, of which we have scant records as far back as 1790 , is then in Kentucky, having come from Maryland, through Pennsylvania. Ben Ishmael had eight children,- - five sons and three 
daughters. Some of the descendants are now living in Kentıcky, and are prosperous, well-regarded citizens. One son named John married a half-breed woman, and came into Marion county, Indiana, about 1840. He was diseased, and could go no further. He had seven children, of whom two were left in Kentucky, one is lost sight of, and one remained unmarried. The remaining three sons married three sisters from a pauper family named Smith. These had children, of whom fourteen lived; and thirteen raised families, having sixty children, of whom thirty are now living in the fifth generation.

Since 1840, this family has had a pauper record. They have been in the almshouse, the House of Refuge, the Woman's Reformatory, the penitentiaries, and have received continuous aid from the township. They are intermarried with the other members of this group, as you may see by the marriage lines, and with over two hundred other families. In this family history are murders, a large number of illegitimacies and of prostitutes. They are generally diseased. The children die young. They live by petty stealing, begging, ashgathering. In summer they "gypsy," or travel in wagons east or west. We hear of them in Illinois about Decatur, and in Ohio about Columbus. In the fall they return. They have been known to live in hollow trees on the river-bottoms or in empty houses. Strangely enough they are not intemperate to excess.

In this sketch, three things will be evident: First, the wandering blood from the half-breed mother, in the second generation the poison and the passion that probably came with her. Second, the licentiousness which characterizes all the men and women, and the diseased and physically weakened condition. From this result mental weakness, general incapacity, and unfitness for hard work. And, third, this condition is met by the benevolent public with almost unlimited public and private aid, thus encouraging them in this idle, wandering life, and in the propagation of similarly disposed children. 
A second typical case is that of the Owens family, also from Kentucky. There were originally four children, of whom two have been traced, William and Brook. William had three children, who raised pauper families.

One son of the third generation died in the penitentiary ; his two sons in the fourth generation have been in the penitentiary; a daughter in the fourth generation was a prostitute, with two illegitimate children. Another son of the third generation had a penitentiary record, and died of the delirium tremens and went to the medical college. There have been several murders; a continuous pauper and criminal record. An illegitimate halfbreed Canadian woman enters this family. There is much prostitution, but little intemperance.

Brook had a son John, who was a Presbyterian minister. He raised a family of fourteen illegitimate children. Ten of these came to Indiana, and their pauper record begins about 1850 . Of the ten, three raised illegitimate families in the fourth generation; and, of these, two daughters and a son have illegitimate children in the fifth generation.

I take these two cases as typical. I could have taken any other one of the thirty; or, indeed, I could have worked out a diagram of two hundred and fifty families as minutely as these.

Returning now to the record, let me call your attention to the following: We start at some unknown date with thirty families. These came mostly from Kentucky, Tennessee, and North Carolina. Of the first generation, $\rightarrow$ of sixty-two individuals, - we know certainly of only three. In the second generation, we have the history of eighty-four. In the third generation, we have the history of two hundred and eighty-three. In the fourth generation,-1840-1860,-we have the bistory of six hundred and forty-four. In the fifth generation,-18601880 , - we have the history of six hundred and seventynine. In the sixth generation,-1880-1890,-we have the history of fifty-seven. Here is a total of 1,750 individuals. Before the fourth generation,-from 1840 to $1860,-$ we have but scant records. Our more com- 
plete data begin with the fourth generation, and the following are valuable. We know of one hundred and twenty-one prostitutes. The criminal record is very large,-petty thieving, larcenies chiefly. There have been a number of murders. The first murder committed in the city was in this family. A long and celebrated murder case, known as the "Clem" murder, costing the State immense amounts of money, is located here. Nearly every crime of any note belongs here. Between 1868 and 1888 not less than five thousand dollars has been paid for "passing" these people from place to place, each township officer trying to throw off responsibility. The records of the eity hospital show that-taking out surgical cases, acute general diseases, and cases outside the city-seventy-five per cent of the cases treated are from this class. The number of illegitimacies is very great. The Board of Health reports that an estimate of still-born children found in sinks, etc., would not be less than six per week. Deaths are frequent, and chiefly among children. The suffering of the children must be great. The people have no occupation. They gather swill or ashes; the women beg, and send the children around to beg; they make their eyes sore with vitriol. In my own experience, I have seen three generations of beggars among them. I have not time here to go into details, some loathsome, all pitiful. I was with a great-grandmother on her deathbed. She had been taken sick on the annual gypsying; deserted at a little town because sick; shipped into the city; sent to the county asylum; at last brought to the miserable home to die. One evening I was called to marry a couple. I found them in one small room, with two beds. In all, eleven people lived in it. The bride was dressing, the groom washing. Another member of the family filled a coal-oil lamp while burning. The groom offered to haul ashes for the fee. I made a present to the bride. Soon after, I asked one of the family how they were getting on. "Oh, Elisha don't live with her any more." "Why?" "Her other husband came back, and she went to him. That made 
Elisha mad, and he left her." Elisha died in the pesthouse. A mother and two girls, present that night, were killed by the cars.

All these are grim facts; but they are facts, and can be verified. More: they are but thirty famlies out of a possible two hundred and fifty. The individuals already traced are over five thousand, interwoven by descent and marriage. They underrun society like devil-grass. Pick up one, and the whole five thousand will be drawn up. Over seven thousand pages of history are now on file in the Charity Organization Society.

A few deductions from these data are offered for your consideration. First, this is a study into social degeneration, or degredation which is similar to that sketched by Dr. Lankaster. As in the lower orders, so in society we have parasitism, or social degradation. There is reason to believe that some of this comes from the old convict stock which England threw into this country in the seventeenth century. We find the wandering tendency so marked in the case of the "Cracker" and the "Pike" here. "Movin' on." There is scarcely a day that the wagons are not to be seen on our streets; cur dogs; tow-headed children. They camp outside the city, and then beg. Two families, as I write, have come by, moving from north to south, and from east to west. "Hunting work"; and yet we can give work to a thoussand men on our gas trenches.

Next, note the general unchastity that characterizes this class. The prostitution and illegitimacy are large, the tendency shows itself in incests, and relations lower than the animals go. This is due to the depravation of nature, to crowded conditions, to absence of decencies and cleanliness. It is an animal reversion, which can be paralleled in lower animals. This physical depravity is followed by physical weakness. Out of this come the frequent deaths, the still-born children, and the general incapacity to endure hard work or bad climate. They can not work hard, and break down early. They then appear in the county asylum, the city hospital, and the township trustee's office. 
Third, note the force of heredity. Each child tends to the same life, reverts when taken out.

And, lastly, note the influence of the great factor, public relief. Since 1840, relief has been given to them. At that time we find that "old E. Huggins" applied to have his wife Barthenia sent to the poor house. A premium was then paid for idleness and wandering. The amount paid by the township for public reliet varies, rising as high as $\$ 90,000$ in 1876 , sinking in 1878 to $\$ 7,000$, and ranging with the different trustees from $\$ 7,000$ to $\$ 22,000$ per year. Of this amount, fully threefourths has gone to this class. Public relief, then, is chargeable in a large degree with the perpetuation of this stock. The township trustee is prastically unlimited in his powers. He can give as much as he sees fit. As the office is a political one, about the time of nomination and election the amounts increase largely. The political bosses favor this, and use it,-now in the interests of the Republican, now of the Democratic party. It thus becomes a corruption fund of the worst kind.

What the township trustee fails to do, private benevolence supplements. The so-called charitable people who give to begging children and women with baskets have a vast sin to answer for. It is from them that this pauper element gets its consent to exist. Charity-falsely so-called-covers a multitude of sins, and sends the pauper out with the benediction, "be fruitful and multiply." Such charity has made this element, has brought children to the birth, and insured them a life of misery, cold, hunger, sickness. So-called charity joins public relief in producing still-born children, raising prostitutes, and educating criminals.

Some persons think it hard that we say to the public, Give no relief to men or boys asking for food, to women begging, to children with baskets, ill-clad, wasted, and wan. "I can't resist the appeal of a child," they say.

Do you know what this means? It means the perpetuation of this misery. "It means condemning to a life of hunger and want and exposure these children. 
It means the education of the street, the after life of vice and crime. Two little boys sell flowers at the doors of church and theatre. They ring bells at night, asking to get warm. Seemingly kind people give them money. They are children of parents who could, if they would, earn enough to support them in comfort. Your kindness keeps them out in the cold. Your own children are warm in bed. They ought to be, but your cruel kindness forces them out in the street. So you are to be made a party to this? You remember the story of Hugo's, "The Man Who Laughs,"-the boy deformed for the sake of the profit it would be? So with these children. They are kept in a life of pain, shut in to misery by the alms of cruel-kind people. And this is why our Charity Organization Society asks you not to give alms, but to give counsel, time, and patience to rescue such as these.

Do any of these get out of the festering mass? Of this whole number, I know of but one who has escaped, and is to-day an honorable man. I have tried again and again to lift them, but they sink back. They are a decaying stock; they can not longer live selt-dependent. The children reappear with the old basket. The girl begins the life of prostitution, and is soon seen with her own illegitimate child. The young of the Sacculina at first have the Nauplius form common to their order. Then the force of inherited parasitism compels them to fasten themselves to the hermit crab. The free-swimming legs and the disused organs disappear. So we have the same in the pauper. Self-help disappears. All the organs and powers that belong to the free life disappear, and there are left only the tendency to parasitism and the debasement of the reproductive tendency. These are not tramps, as we know tramps, nor poor, but paupers.

What can we do? First, we must close up official out-do ,r relief. Second, we must check private and indiscriminate benevolence, or charity, falsely so-called. Third, we must get hold of the children. 